\title{
PSEUDORABIES VIRUS GROWTH FACTOR (PRGF) FACILITATES THE GROWTH AND POSTNATAL DEVELOPMENT OF MICE AND RATS
}

\author{
M. CSABAYOVA ${ }^{1}$, J. LEŠKO ${ }^{1}$, M. DUŠINSKA ${ }^{2}$, J. GAŠPERIK ${ }^{3}$, F. GOLAIS ${ }^{4 *}$ \\ ${ }^{1}$ Institute of Virology, Slovak Academy of Sciences, 84246 Bratislava, ${ }^{2}$ Cancer Research Institute, \\ Slovak Academy of Sciences, 81232 Bratislava, ${ }^{3}$ Institute of Molecular Biology, Slovak Academy of Sciences, \\ 84251 Bratislava, and ${ }^{4}$ Comenius University, Department of Microbiology and Virology, \\ 84246 Bratislava, Slovakia
}

Received May 16, 1995

\begin{abstract}
Csabayová M., J. Leško, M. Dusinská, J. Gašperík, F. Golais: Pseudorabies Virus Growth Factor (PGRF) Facilitates the Growth and Postembryonal Development of Mice and Rats. Acta vet. Brno 1995, 64:249-255.

PRGFA, one of two components of pseudorabies virus (PRV) growth factor (PRGF) facilitated the growth and postnatal development of newborn BALBc mice and outbred albino Wistar rats, when administered subcutaneously. The growth proceeded much more rapidly and the initiation of hair growth appeared considerably sooner in PRGFA treated than in control animals. Susceptibility to PRGFA decreased with age, two days old animals proved to be the most susceptible and became non-susceptible at the age of 12 days.

Two monoclonal antibodies (moabs) directed against gII glycoprotein of PRV neutralized the growth stimulating activity of PRGFA. Considering these findings, PRGFA is discussed as a potential novel growth stimulator.
\end{abstract}

Pseudorabies virus, viral growth factor, newborns, mice, rats, growth stimulation

Pseudorabies virus growth factor (PRGF), possessing dual, transforming and transformed phenotype repressing activity was detected in certain pseudorabies virus (PRV) infected and transformed cells (Golais et al. 1990; Golais et al. 1992). Purification of PRGF by discontinuous recycling chromatography revealed that this factor consists of two components, $\mathrm{PRGF}_{\mathrm{A}}$ and $\mathrm{PRGF}_{\mathrm{B}}$. Each of these components alone is sufficient for transforming activity, whereas for transformed phenotype repressing activity both components are required. Two monoclonal antibodies (moabs) No. 36 and 68 (Qu ist et al. 1989) directed against gII glycoprotein of PRV were shown to neutralize both PRGF activities, thus indicating that PRV gene for gII might be involved in PRGF synthesis (Gašperík et al. 1994).

The described effect of PRGF on normal and transformed cells (Golais et al. 1990) might be of particular interest in studies of tumour formation, progression or inhibition. Before testing PRGF in tumour bearing animals, its effect on normal suckling mice and rats has been studied and presented in this paper.

\section{Materials and Methods}

P r e p a r a t i o n of P R G F. Semipurified PRGF containing both components as well as its two purified components $\mathrm{PRGF}_{\mathrm{A}}$ and $\mathrm{PRGF}_{\mathrm{B}}$ were prepared by procedure developed by Gašperík et al. (1994). All three PRGF samples were further used for inoculation of animals.

\footnotetext{
$4^{*}$ corresponding author

Authors state that all procedures using animals were performed in accordance with European Convention for the Protection of Vertebrate Animals Used for Experimental and Other Scientific Purposes (1986).
} 
A $\mathrm{n}$ i $\mathrm{m}$ a $1 \mathrm{~s}$. Conventional BALB/c/J/Ham mice, originated from Laboratory Animal Institute Hannover, Germany and conventional Wistar rats were obtained from VELAZ, Prague, Czech Republic. The cages (VELAZ, Prague) of T II type (bottom area $333 \mathrm{~cm}^{2}$ ) were used for housing of mice and T III type (bottom $738 \mathrm{~cm}^{2}$ ) were used for rats in "open systems". The cages made of polypropylene were transparent for daily light. Sterilized, dried, soft and dust-free wood shavings used for bedding were changed daily. The room temperature was kept at $22+1{ }^{\circ} \mathrm{C}$, relative humidity at $55 \pm 10 \%$. Natural daylight, and an 8-10-fold air change in the room per hour was provided. The animals were maintained on a standard laboratory diet (ST - 1 feed, VELAZ, Prague) with drinking water available ad libitum.

I n o c u l a t i o n of a n i m a $1 \mathrm{~s}$. Phosphate buffered saline $(50 \mu \mathrm{l})$ at $\mathrm{pH} 7.2$, containing $10^{6}$ units of PRGF, PRGF $_{A}$ or PRGF $_{B}$ (for definition of PRGF unit see Golais et al. 1992) was injected subcutaneously, intraperitoneally or given orally to two-day-old BALBc mice, or subcutaneously to three-day-old outbred albino Wistar rats, observing the guidelines recommended by NIH Animal Care and Use Committee. Six mice or 8 rats from each litter were always randomly chosen for inoculation and kept in one cage. Sham-inoculated animals were given $50 \mu \mathrm{l}$ intact saline, a group of the control animals was kept intact, i.e. without any inoculation. The body mass and body length of animals were determined daily. The animals repeatedly inoculated with the same amounts of PRGF (administered at $48 \mathrm{hrs}$ intervals) were compared with those inoculated once only. The results were statistically evaluated by Student's t-test.

$\mathrm{N}$ e u t r a li z a t i o n of P R G F. All three PRGF samples were neutralized with two moabs, No 36 and 68 directed against gII of PRV. Moabs were obtained from Veterinary Serum Laboratories Copenhagen, Denmark (Qvist et al. 1989) and were previously shown to neutralize the PRGF activity in vitro (Gašperík et al. 1994). This neutralization method was described previously (Golais et al. 1992).

\section{Results}

\section{The effect of PRGF and its separated components on newborn} $\mathrm{mice}$

PRGF administered subcutaneously was shown to enhance the growth and to facilitate the postembryonal development of mice. PRGF-treated animals grew much more rapidly as compared to the sham-treated ones whose growth did not substantially differ from intact controls. Moreover, PRGF-treated mice became pilous as soon as 3-4 days after inoculation while hair growth in the sham-inoculated animals initiated 4-5 days later. However, there were some differences in growth enhancement between the non-resolved PRGF and its two separated components. PRGF $_{\mathrm{A}}$ proved to be the most effective growth stimulator, whereas

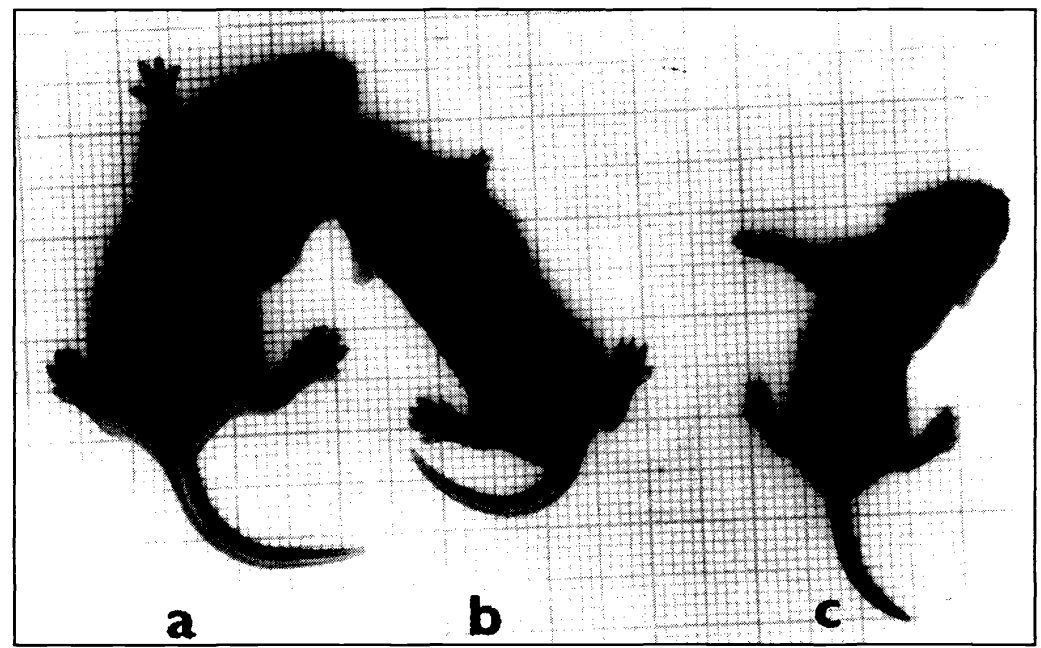

Fig. 1. The effect of PRGF on suckling BALBc mice $24 \mathrm{hrs}$ after subcutaneous administration. a) mouse treated with PRGFA; b) mouse treated with non-resolved PRGF; c) sham-inoculated mouse. 
non-resolved PRGF and PRGF $B$ were less efficient (Fig. 2). Mice inoculated with PRGF and PRGF $_{\mathrm{A}}$ are shown in Fig. 1.

Following intraperitoneal administration no significant growth differences were obtained with non-resolved PRGF, PRGF $\mathrm{B}$ and sham control, only PRGF $_{\mathrm{A}}$ caused a limited shortterm effect (Fig. 3). Both resolved and non-resolved PRGF samples elicited no effect in mice when administered orally ( data not shown).

The growth stimulating effect of PRGF following subcutaneous inoculation was observed only during a 17-19-day long time period with maximum differences from control animals between days 2 and 12 after inoculation. The body mass and length of all tested animals became approximately equal at about day 18 after initial PRGF administration (Figs 2 and 3ab).

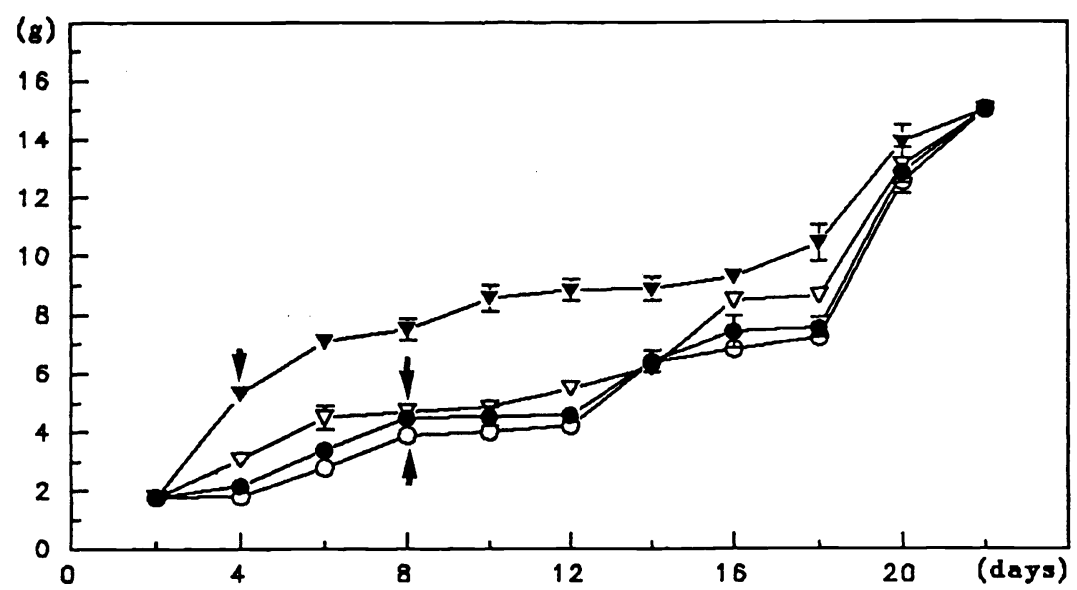

Fig. 2. The effect of $P R G F$ and its two separated components $\left(\mathrm{PRGF}_{\mathrm{A}}, \mathrm{PRGF}_{\mathrm{B}}\right)$ on growth of newborn mice. Subcutaneous administration. Hair growth initiation is shown by arrows. The means of body mass and standard deviations were calculated from 6 repeated experiments including more than 35 animals in each time point. The t-test was used for statistical analysis. The means of the weight of $\mathrm{PRGF}_{\mathrm{A}}$ treated and control animals were different at the $\mathrm{P}<0.05$ level at $4-18$ days. The body mass means of the PRGF-treated and control animals were different at the $P<0.05$ level at $4-12$ days.

O-O sham-inoculated controls, $-\longrightarrow \mathrm{PRGF}_{\mathrm{B}}, \nabla-\nabla$ non-resolved PRGF, $\boldsymbol{\nabla}-\boldsymbol{\nabla} \mathrm{PRGF}_{\mathrm{A}}$.

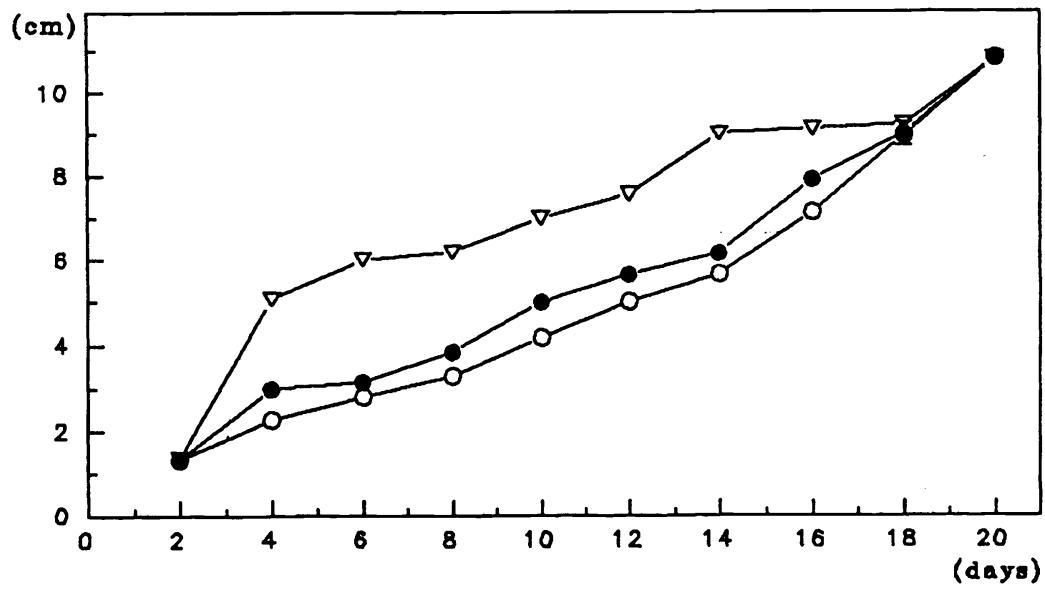

Fig. 3a (for text see p. 252) 


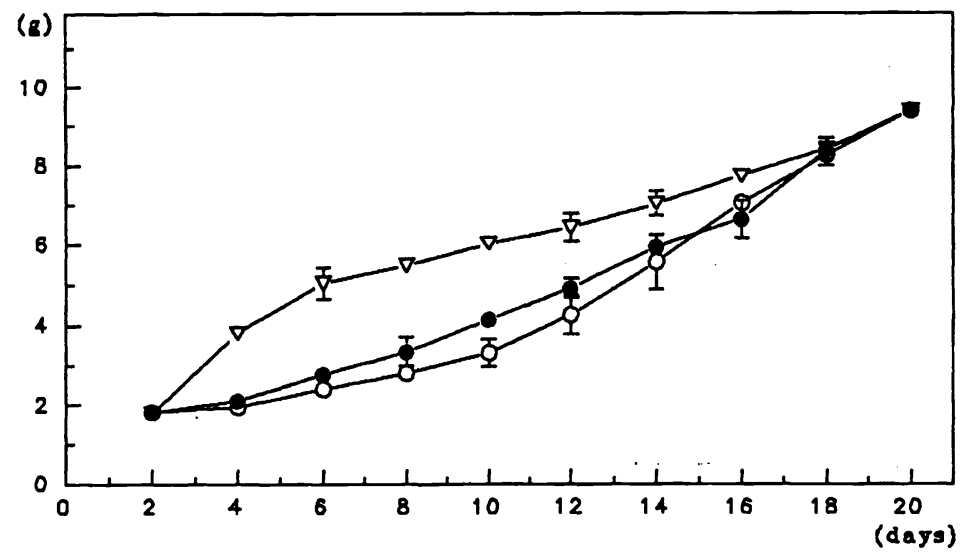

Fig. 3b Comparison of subcutaneous and intraperitoneal administration of $\mathrm{PRGF}_{\mathrm{A}}$ on the size (Fig.3a) and body mass of mice.

The body mass means and standard deviations were calculated from 6 repeated experiments including more than 35 animals in each time point.The t-test was used for statistical analysis. At subcutaneous administration of $\mathrm{PRGF}_{\mathrm{A}}$, the means of the body mass and size of treated and control animals were different at the $P<0.05$ level at $4-16$ days. O-O shamsham-inoculated controls, $-\odot$ intraperitoneal administration, $\nabla-\nabla$ subcutaneous administration.

Repeated inoculation of mice at $48 \mathrm{hrs}$ interval was a prerequisite for observed growth enhancement. Otherwise, when after the first inoculation no further challenges took place, the growth enhancement stopped within the next 4-5 days.

All PRGF samples lost their ability to enhance the growth of mice when treated either with moab 36 or 68, or both. Fig. 4 shows the effect of moab 36 on PRGFA activity (other data are not shown).

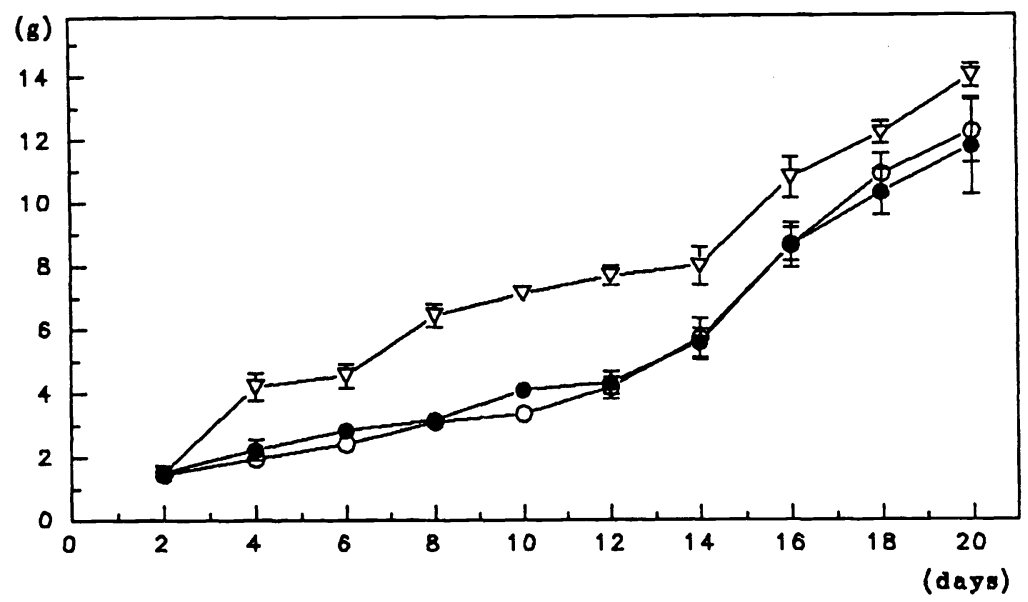

Fig. 4. The effect of moab 36 on growth stimulating activity of $P_{R G F}$. Subcutaneous administration of mice. The body mass means and standard deviations were calculated from 6 repeated experiments including more than 35 animals in each time point.The $t$-test was used for statistical analysis. At subcutaneous administration of PRGF $_{A}$, the body mass means and size of treated and control animals were different at the $P<0.05$ level at $4-20$ days. O-O sham-inoculated controls, $\nabla-\nabla$ PRGFA, - moab treated PRGF $_{\mathrm{A}}$. 


\section{Age-dependent susceptibility to PRGFA}

In these experiments, mice of different ages were treated with the same amount $\left(10^{6}\right.$ units $)$

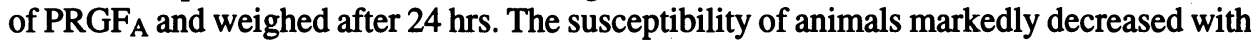
age. Mice aged 2 days showed highest susceptibility, their body mass was about $150 \%$ higher as compared to $100 \%$ in sham-inoculated controls. Animals aged 4 days reached about $75 \%$, and those aged 6 days about $50 \%$ body mass increase. Mice at 8 days of age showed about $45 \%$ body mass increase, and at the age of 12 days all animals became nonsusceptible to PRGF $_{A}$ (see Fig. 5).

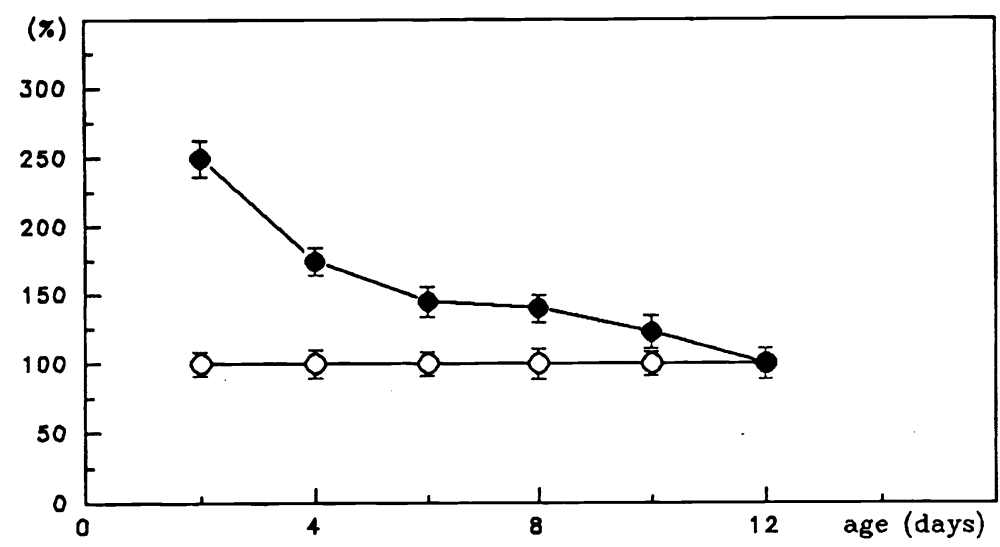

Fig. 5. Susceptibility of mice of different age to $P_{R G F}$. The animals were inoculated by $P R_{A F}$ at different ages and the next day the body mass of treated animals were measured and compared to their respective controls. The body mass of the controls at each age is $100 \%$. Repeated experiments included about 30 animals from each age category. - - PRGF $_{\mathrm{A}}$ treated animals, $\bigcirc-O$ sham-inoculated controls.

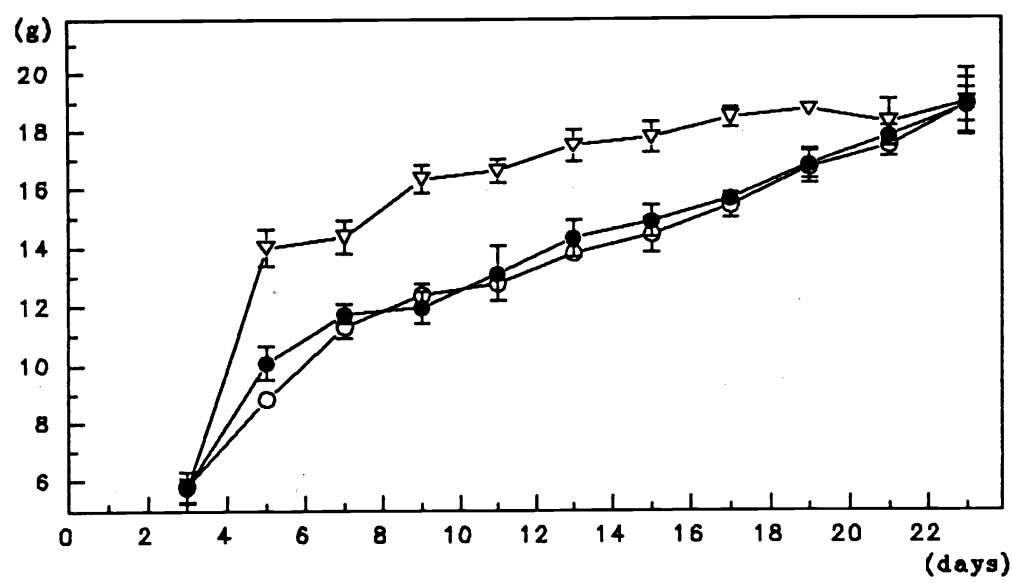

Fig. 6. Growth stimulating effect of $\mathrm{PRGF}_{\mathrm{A}}$ on 3-day-old rats and the effect of moab 68. Subcutaneous administration. The means body mass means and standard deviations were calculated from 6 repeated experiments including more than $\mathbf{4 5}$ animals in each time point. The t-test was used for statistical analysis. At subcutaneous administration of PRGF , the means of the body mass and size of treated and control animals were different at the $P<0.05$ level at 5 - 19 days.

O-O sham-inoculated control, $\nabla-\nabla$ PRGFA, - PRGFA treated with moab. 
The effect of longterm administration of PRGFA

Sixty mice aged 2 days were inoculated subcutaneously with $\mathrm{PRGF}_{\mathrm{A}}$ and kept for 4 months along with 18 sham-treated and 18 non-treated animals (male and female animals were kept separately). In the first 4 weeks, $10^{6}$ units were inoculated into each animal at 48 hrs intervals, later on $2 \times 10^{6}$ units were administered twice weekly. During the period under study, PRGF-treated animals did not differ in any respect (weight, size, behaviour) from those sham-inoculated or non-inoculated (besides the above mentioned 17 days time span). No tumors or visible pathological findings as revealed by autopsy were found in animals kept in the long-term experiment under PRGF treatment.

The effect of PRGF on suckling rats

PRGF $_{A}$ introduced subcutaneously into 3-day-old rats induced a similar growth stimulating effect as was observed in mice. It was similarly neutralized by two moabs against gII of PRV. Fig. 6. shows the effect of moab 68 on PRGF $_{A}$.

\section{Discussion}

PRGF, a novel viral growth factor detected in certain PRV infected and transformed cells was shown to have two effects on cultured cells in vitro. Non-transformed cells cultivated in the presence of PRV acquired the phenotype pertain to transformed cells ("criss-cross" pattern of growth, anchorage independence in soft agar), whereas the phenotype of transformed cells became converted towards the normal one (Golais et al. 1990).

Purification of PRGF by discontinuous recycling chromatography revealed that this factor consists of two components, $\mathrm{PRGF}_{\mathrm{A}}$ and $\mathrm{PRGF}_{\mathrm{B}}$. Each of these two components is sufficient for manifestation of transforming activity, whereas for transformed phenotype repressing activity, either non-resolved PRGF, or both components acting simultaneously are required (Gašperík et al. 1994).

The aim of our further studies is the testing of PRGF and its two components in vivo. Especially the transformed phenotype repressing activity of PRV observed in vitro might be under certain circumstances utilized in prevention of tumour formation or progression. In the first step of this research program, PRGF and its two components have been tested in suckling mice and rats in attempts to demonstrate, or rule out their oncogenicity in vivo. It has been surprisingly shown, that PRGF, especially the PRGF $A$ component facilitates the growth and development of suckling mice and rats. Long-term keeping of mice under $\mathrm{PRGF}_{\mathrm{A}}$ treatment have not resulted in appearance of tumours. We are aware of the fact that based on these results there is no reason to believe, that PRGF possess absolutely no oncogenic activity in vivo. More profound studies are required for such conclusion. Of special interest is the interaction of PRGF with endocrine and immune systems. Nevertheless, PRGF being shown to enhance the growth and facilitate the development of newborn mice and rats appears to be very tempting for further studies, as it might find some applications in animal husbandry. As PRGF is at present only one known herpes virusrelated growth factor, characterized in our laboratory, the findings presented in this paper, as well as the results reported in Golais et al. (1990), Golais et al. (1992) and Gašperík et al. (1994) could not be related to any other published studies.

\section{Rastový faktor vírusu pseudorabies (PGRF) urýchluje rast a postembryonálny vývoj myší a potkanov}

PGRF $_{\mathrm{A}}$, jedna $\mathrm{z}$ dvoch zložiek PGRF, po subkutánnej aplikácii urýchluje rast a postnatálny vývoj novorodených myší a potkanov outbrednej línie Wistar. V skupinách 
zvierat, ktorým sme aplikovali $\mathrm{PGRF}_{\mathrm{A}}$, nastal urýchlený rast a skoršie osrstenie ako v skupinách kontrolných. ÚCinok PGRF ${ }_{\mathrm{A}}$ závisel od veku zvierat: najúcinnejší bol u mládat dvojdňových, ale u mládat starších ako 12 dní bol neúčinný. Dve monoklonové protilátky proti GII glykoproteínu vírusu pseudorabies neutralizujú rast stimulujúcu aktivitu $\mathrm{PRGF}_{\mathrm{A}}$. $\mathrm{V}$ práci sa diskutuje použitie $\mathrm{PGRF}_{\mathrm{A}}$ ako nového potenciálneho stimulátora rastu.

\section{References}

GAŠPERIK, J., LEŠKO, J., CSABAYOVÁ, M., GOLAIS, F. 1994: Pseudorabies virus growth factor (PRGF) can be resolved into two active components. Acta. virol. 38:117 - 120

GOLAIS, F., LEŠKO, J., HILLEROVÁ, A., KOLCUNOVÁ, A., SABO, A. 1990: A putative virus-encoded growth factor in a crude extract of pseudorabies virus infected and transformed human cells. Biol. Zbl. 109: 481487

GOLAIS, F., CSABAYOVÁ, M., LEŠKO, J., BYSTRICKÁ, M., SABO, A. 1992: Herpes simplex virus type 2 and pseudorabies virus associated growth factors and their role in the latency in vitro. Acta. virol. 36:505-515 QVIST, P., SORENSEN, K. J., MEYLING, A. 1989: Monoclonal blocking ELISA detecting serum antibodies to the glycoprotein gII of Aujezsky's disease virus. J. virol. Meth. 24:169-180 